\title{
色材協會 誌
}

第 17 卷 第 12 號。昭和 18 年 12 月

\section{報文一}

\section{顔料の防唀效果に及す體質顔料の影響}

第 1 報 試 驗の目的及試驗方法

日本化工鉒粼楼式會社 松 本 元

\section{序}

油ペイントに於ては單一の噋料が單獨で㜔用されるこ とは少く、多くは2種以上の蘱料を混合して使用して居 る。殊に粒子の形狀及び大さを異にする 2 種以上の頝䊀 を混用する時は染膛內に於ける頝料の詰まり具合を密に して塗莫の耐久力を習すと言はれて居る。此の意味に於 て體質顏料の混用も輕哯す可きではない。

さて防銹染料に對する體筫頞楼の影響に就いては、白

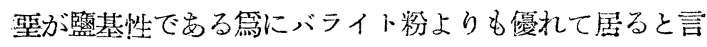

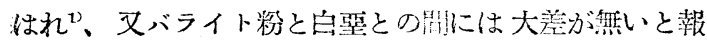
告された例も安り 22 、文鉆丹に對してはバライト粉の方 が却つて白㤠に優る ${ }^{32}$ と報告されて居る等其の效果に 對しては定說が無い。

亦雲母粉はリーフイング性を有し、濕氣の透過を妨げ 殊に防唋效果を墫加すると言はれて居る。

著者は體質顔料の添加が防銹染料の耐候性に及正影響 を知る焉に、我が國で入手し易い體質顮料數理に就いて 實驗を行つたので、以下に其の結果を報告する。

試料

體質顏料としてはバライト粉、白裂、滑石粉、ヂャイ ナクレー、雲母粉等、本邦で最も普通に使用されて居る もの、又は最も入手し易いるのを撰んだ。

其の分析の結果は次表の如くである。

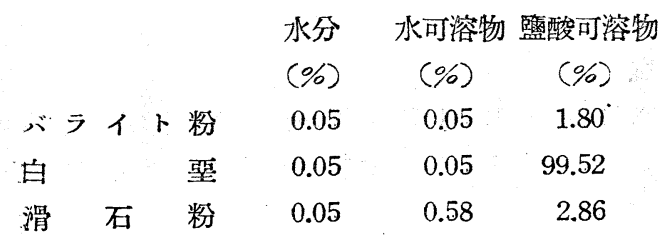

$\begin{array}{crrrr}\text { チャイナクレー } & 0.22 & 0.12 & 1.26 \\ \text { 雲 母 粉 } & 0.12 & 0.45 & 2.34\end{array}$

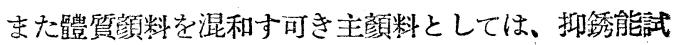
驗らに供した下記の 5 䅜孛用ひた。

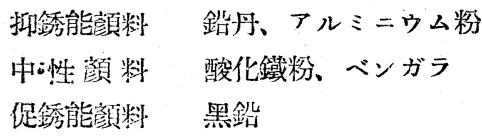

之等各顔料の分析值に就いては各報に於て述べるとと とし、此處には省略する。

試驗用ペイントの作整

各顏料に軆質顔料を加へ、竟蕉油と練り合せて試驗用 のペイントを作つた。

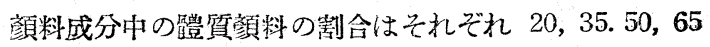
80\%となるやうに噀んだ。”猖し鉛丹の場合には特に 10， $20 ， 30.40 ， 50 ， 60$ 及び $80 \%$ と六。

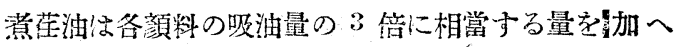
た。但しアルミニウム粉の場合には吸油量が明確でない。 ので、其の重量の獍に相當する量の油を加へた。 各顏料の吸油量を装示すると次の如くで岗る。

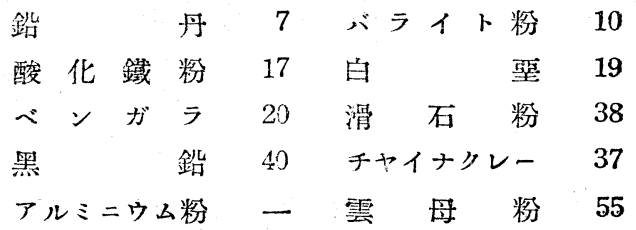

顏料を提練調合するのに用ひた惹嚄油の性狀は次表の 如くである。

$\begin{array}{lr}\text { 酸 價 } & 1.9 \\ \text { 沃素價 } & 192.5\end{array}$


粘度 0.5 ポイズ

\section{曝露詿驗方法}

上記の如くにして得た試驗ペイントを $22 \times 15 \times 0.1 \mathrm{~cm}$ の㜞鋼板に $0.6 \mathrm{~g} / \mathrm{dm}^{2}$ の割合で塗布し、塗布後 1 週間 の後に 45 度傾拣、南面して曝露した。

試驗用鐵板の前處理、試驗板の調製、曝露の方法等に 就いては、前報告の“黑鉆ペントの防銹效果”中の試 驗方法に準じて行つた。

\section{曝露成績の表記方法}

曝露した試驗板は 1 箇月每に㳊膜の狀態主として發銹 の有無を檢し、其の狀態を記號を用ひて記銭した。

次に使用した記號に就いて說明する。

$\mathrm{S}$ ：塗面にしみ狀の變色を生じたもの。黄、淡茶褐色 又は鼠色等を帶びたよごれ、又はしみ狀を是す。 塗膜下の發銹に起因す。

b：湮面の小突起にして粟粒狀を呈す。

$B$ : 秷面のふくれにして $b$ よりも徑及び高さ大にし て、時に其の頂點の破れたものもある。

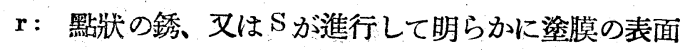
に銹として現はれたもの、:又は點狀の銹が密集し て濕㐱狀となつたもの。

$\mathrm{R}$ : 銹が染朕を貫いて表面に現はれ、且其の鰘が $2 \mathrm{~mm}$ 以上に及ぶもの。

$\mathrm{F}:$ 銹の爲に塗膜が剝離して溙地の鐵面が露出したも の。

上記の缺陷が塗膜に現はれな程度を示す爲に、各缺陷 が染面中で占める割合の數字を記號の右下に附した。例 へば $\mathrm{R}_{2}$ は Rなる铁陷が雓面の20\%を占めた事を示す。
數字が大なる程缺陷の著しいことを赤し、數字を附せず 記號のみを記したものは其の記號で現される缺陷が僅に 起つた事を意味して居る。

また數種の缺陷が同時に起つた場合には、比較に便利 な缺陷及び其の程度を示し、其の他の缺陷は括弧內に列 記して置いた。例へば $\mathrm{R}_{5}\left(\mathrm{~B}_{3} \mathrm{~F}_{1}\right)$ は、全體としては $\mathrm{R}_{5}$ で塗膜の缺陷を代表せしめたが、同時に括弧內の記號で 示された缺陷も起つて居た事を示す。即ち筀膜の約 50 \%に發銹があり、同時に約 10\%の剝㒕と、30\%の泡起と え゙發銹部位に起つて居たことを示して居る。

また $\mathrm{S}_{3}\left(\mathbf{r}_{1}\right)$ は塗膜の約 30\%が黄茶色に變色し、其の 中で約 $10 \%$ 部分には繁銹が見られた事を示し、 $\mathrm{R}_{2}\left(\mathrm{~S}_{2}\right)$. は塗膜の約 $20 \%$ に塗膜を貫いて表面に現はれた稍大き な銹が見られ、其の外に約 $20 \%$ の黄茶色に變色した部 分があることを示して居る。

以下に篇を改めて各試驗成績に就いて報告する。

\section{文 献}

1) Scheiber-Sändig: Farben Ztg., 1926, 31, 981.

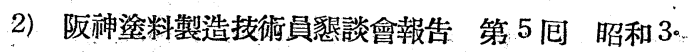
10.

3) Marwedel, G., Kolloid Zeitsch., 1938, 48, 141 226; Farben Ztg., 1939, 44, 249., 廣瀨誠一: 色材 誌 1940 14, 81.

4) Jordan, L. A. \& L. Whitby: The Pres of Iron \& Steel by Means of Paint P 146.

5) 松本十九: 色材誌 1942, 16, 234.

6) 松本十九：色材誌 1940, 14, 159 65, 287 91. $307 \sim 11,341 \sim 4$.

\section{顔料の防敘効果に及す體質顔料の影響}

\section{第 2 報 酸化鐵粉一體質顏料系}

序

酸化鐵粉に各種の體質顏料を混用した場合の防銹効果 に就レて實驗した。

試驗に用ひた酸化鐵粉は次表の如くである。 水分 $0.45 \%$

鹽酸不溶物 7.46
日本化工㳓料株式會社 松、本十九

$\begin{array}{lc}\text { 酸化鐵 } & 90.23 \\ \text { 水可溶物 } & 1.20 \\ \text { 水浸出液 } \mathrm{pH} & 7.2\end{array}$

\section{試驗成樍}

昭和 16 年 12 月 17 日以降霂 1 筒年牛の間、淡橋區 角筈在の熬社工場の屋上に於て曝露試驗した結果は次表の如くであつた。 
體 質顏 料 の

名 䊈混合顏料中 混合顏料中 0

バライト粉 20

35

50

65

80

出

滑石 粉 20

20

35

50

65

$80^{\circ}$

35

50

65

80

チャイナクレー 20

35

50

65

80

雲 日 粉 20

35

50

65

80 3 䇠月後 6 筒月後

$\mathrm{S}_{1}$

$\mathrm{S}_{6}$

$r_{1}$

$r_{1}$

$r_{2}$

$\mathrm{S}_{3} r_{1}$

$\mathrm{S}_{5} r_{2}$

$\mathrm{S}_{5} r_{3}$

$\mathrm{S}_{5} r_{4}$

$r_{3}$

$\mathrm{S}$

$\mathrm{S}$

$\mathrm{S}$

$\mathrm{S}$

$\mathrm{S}$

$\mathrm{S}$

$\mathrm{S}_{4}$

$\mathrm{S}_{8}$

$\mathrm{S}_{8}$

$\mathrm{S}_{10}$

$\mathrm{S}_{2}$

$S_{1}$

$S_{1}$

\section{曝露成綪の考察}

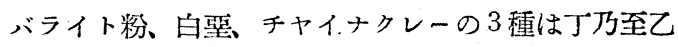
上の成績を示し、あまり成續はよくなかつた。之等の體 質顏料は一般に涯加量が多くなる程成䥊は惡くなつた。

白裂はバライト粉及びチャイナクレーより惡い成績を 示した。

滑石粉及び雲母粉は共に良い成績を示した。此の 2 種 の顏料は概して添加量が多くなる程良い成績を示し、何 れも $80 \%$ 加へた時に最も良い成績を示した。

滑石粉よりも雲母粉の方が稍良い成績を示した。但し
試驗 の 成 績

12 筒月後 18 筒月後概評 $\mathrm{S}$

$\mathrm{S}_{\mathrm{c}}$

$r_{1}\left(\mathrm{~S}_{8}\right)$

$r_{2}\left(\mathrm{~S}_{5}\right)$

$r_{3}\left(\mathrm{~B}_{1} \mathrm{~S}_{7}\right)$

$r_{3}\left(b_{2} \mathrm{~S}_{6}\right)$

$r_{4}\left(b_{3} \mathrm{~S}_{e}\right)$

$r_{3}\left(b_{6} \mathrm{~S}_{6}\right)$

$r_{5}\left(b_{4} \mathrm{~S}_{5}\right)$

$r_{2}\left(b_{4} \mathrm{~S}_{5}\right)$

$r_{4}\left(\mathrm{~S}_{6}\right)$

$r_{8}$

$r_{0}$

$r_{10}$

电

乙

$r_{2}\left(\mathrm{~B}_{1} \mathrm{~S}_{6}\right)$

$r_{3}\left(\mathrm{~S}_{2}\right)$

$r_{3}\left(\mathrm{~S}_{7}\right)$

$r_{6}\left(\mathrm{~S}_{2}\right)$

$r_{7}\left(\mathrm{~S}_{2}\right)$

$r_{0}$

$\mathrm{S}_{3}$

$\mathrm{S}_{5}$

$S_{5}$

$\mathrm{S}_{\tau}$

$\mathrm{S}_{1}$

$\mathrm{S}_{1}$

$r_{1} \mathrm{~S}_{5}$

$r_{4} S_{3}$

$r_{6} \mathrm{~B}_{6}$

$r_{0} \mathrm{~B}_{\mathrm{B}}$

$r_{3}\left(\mathrm{~S}_{4}\right)$

$\mathrm{S}_{3}(r)$

$r_{1}\left(\mathrm{~S}_{3} \mathrm{~B}\right)$

$\mathrm{S}$

$\mathrm{S}$

$r_{1}\left(\mathrm{~S}_{4}\right)$

乙下

两上

乙下

两

乙

乙下

死

I

J

$r_{1}\left(b_{3} \mathrm{~S}_{5}\right)$

乙上

$r_{2}\left(\mathrm{~B}_{4} \mathrm{~S}_{5}\right)$

乙

$r_{3} \mathrm{R}_{1}\left(\mathrm{~B}_{5} \mathrm{~S}_{4}\right)$

乙

$r_{1} \mathrm{~S}_{1}$

乙下

$\mathrm{S}_{4}\left(\mathrm{~B}_{4}\right)$

甲

$r\left(\mathrm{~S}_{7} \mathrm{~B}_{6}\right)$

乙上

$r_{4}\left(b_{6} \mathrm{~S}_{6}\right)$

乙

$r_{7}\left(b_{8} \mathrm{~B}_{1} \mathrm{~S}_{3}\right)$

乙下

$r_{10}\left(b_{10}\right)$

时

$r_{2}\left(\mathrm{~B}_{6} \mathrm{~S}_{\theta}\right)$

$\mathrm{S}_{4}\left(b_{2}\right)$

$r_{3}\left(\mathrm{~B}_{5} \mathrm{~S}_{6}\right)$

$r_{2}\left(\mathrm{~B}_{2}\right)$

.

$r_{1}$

甲

雲母粉は添加量が多くなると塗り難くなる缺點がある。 之等 5 種の體質顏料の 5 ち最も早く染膜に缺陷を現は し始めたのは、白亚及びチャイナクレーの 2 種で、最も おそく缺陷が現はれたのは滑石粉であつた。

\section{總 括}

酸化鐵粉は哣質顏料の添加に依つて其の防銹効果を低 減されるが、滑石粉及び雲母粉を多量に加へた時には輿 影響がなかつた。

體質顏料を加へた時、雲母粉、滑石粉、バライト粉、 チャイナクレー、白堅の順序に成績は惡くなつた。 


\section{顔料の防銹效果に及す體質顔料の影響 \\ 第 3 報 ベンガラ一體質顏料系}

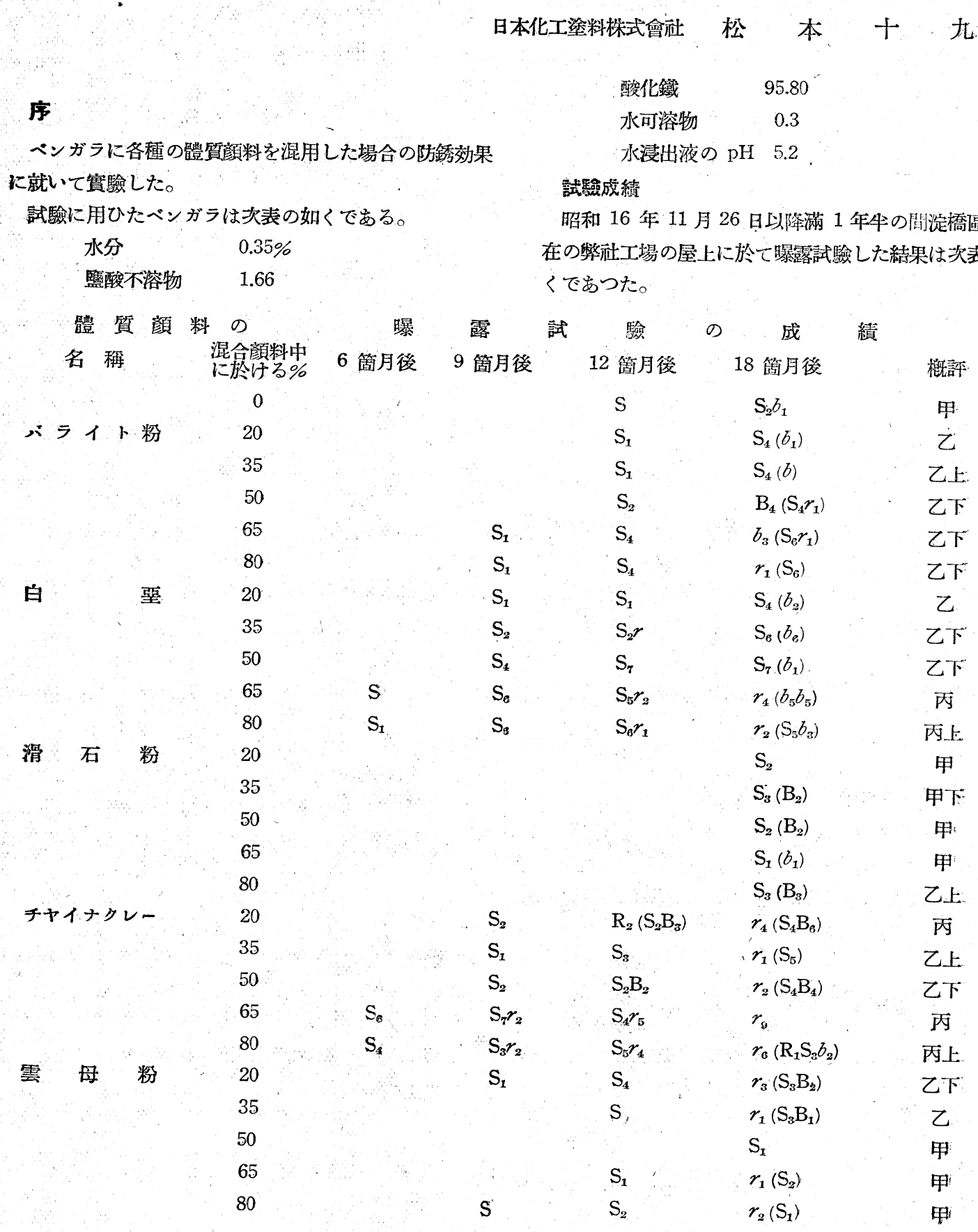




\section{曝露成續の考察}

一般に體質顏料の添加はベンガラの防銹効果を害す る。

バライト粉、白堅及びチャイナクレーの添加は特に惡 い成績を示した。

バライト粉及び白忹は 20〜50\%を涯加した場合には 略同じ成績を示したが、65\%以上加へると白珲が著しく 成績を低下したのに区して、バライト粉の成續低下は著 しくなかつた。チヤイナクレーは白裂と同じく $65 \%$ 以 上加へると著しく成績を低下した。

滑石粉及び雲母粉は共に良い成績を示した。滑石粉は 添加量が多過ぎると成績を低下する傾向圭示したが、雲 母粉は之に反して添加量の多い方が良い成績交した。
之等 5 種の體質顏料のうち、最も早く塗膜に缺陷を表 はし始めたのは、白珲及びチャイナクレーの 2 種て、最 もおそく触陷を生じたのは滑石粉であつた。

總 括

ベンガラに體質顏料在加へた時、バライト粉、白亚及 びチヤイナクレーは惡い成績を示し、滑石粉は影響なく、 雲母粉は添加量が少いと惡いが多くなると良い成績を示 した。

成績は滑石粉、雲母粉、バライト粉、白哑、チヤイナ クレーの順序に惡くなつた。

バライト粉と自裂との差は添加量が少い時は著しくな いが、多くなると白壁の方が著しく惡くなる。

\section{顔料の防銹效果に及す體質顔料の影響}

\section{第. 4 報 黑鉛一體質顏料系}

日本化工塗料株式會社 松本十九

序

黑鉛に各種の體質頝粼を混用した場合の防銹效果に就

いて實驗した。

試驗に用ひた黑鉛は次表の如くである。

$\begin{array}{ll}\text { 水分 } & 0.45 \% \\ \text { 粗粒分 } & 1.35 \\ \text { 炭素 } & 81.82\end{array}$

$\begin{array}{lc}\text { 水可溶物 } & 0.18 \\ \text { 水浸出液の } \mathrm{pH} & 6.8\end{array}$

\section{試驗成績}

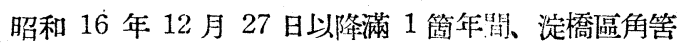
在の㢣社工場の屋上に於て暴露試驗した結果は次表の如 くであつた

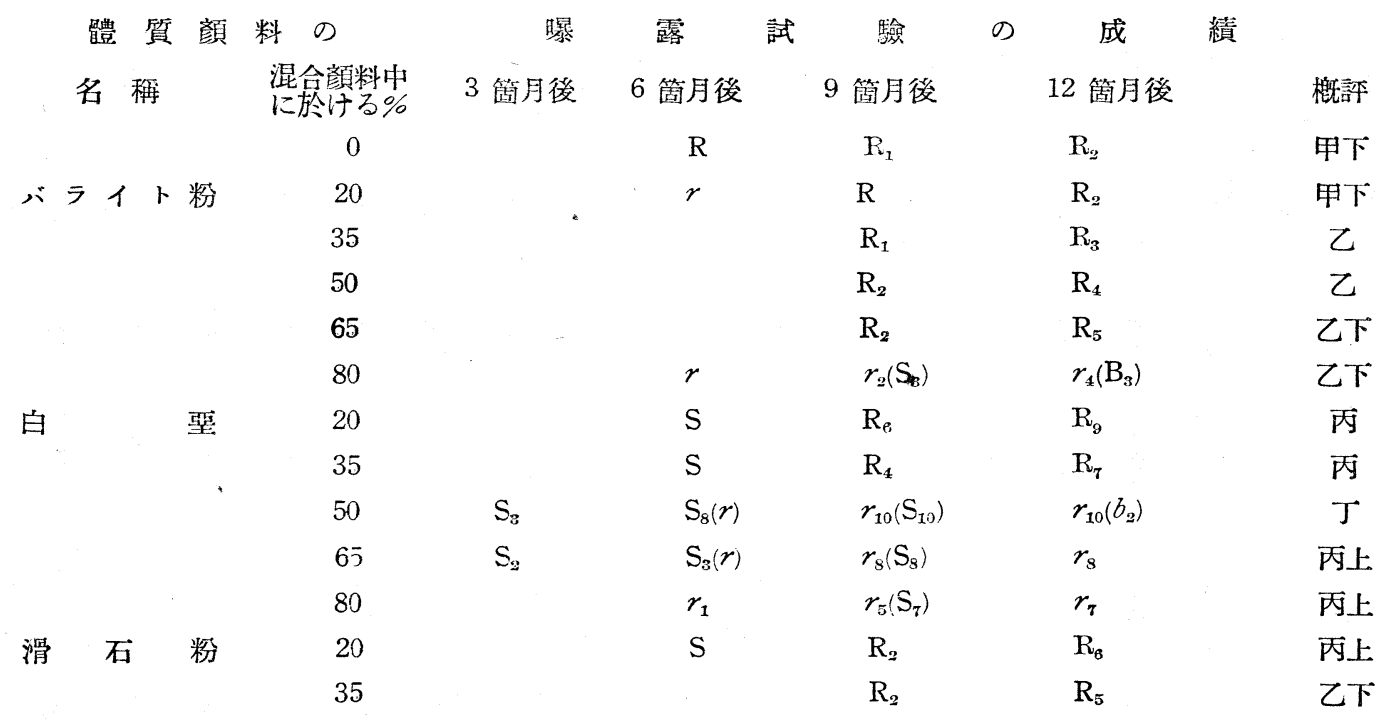




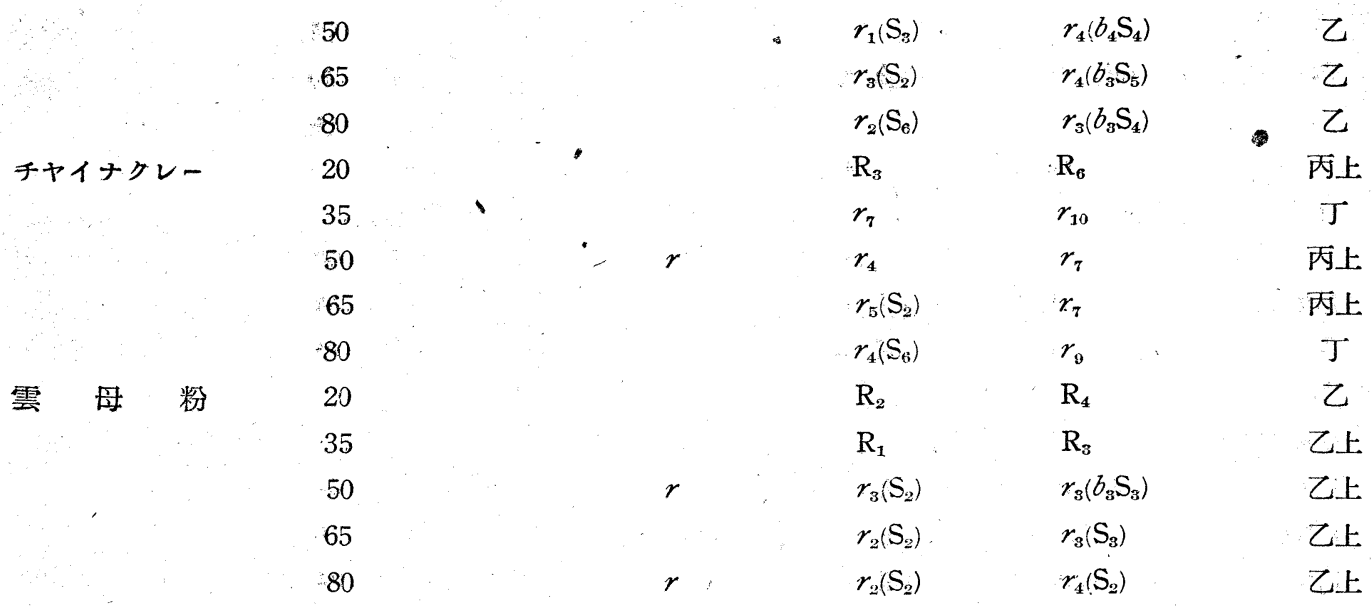

\section{曝露成綪の考察}

一般に體質領料の涯加は黑鉆の防銹効果を低下する。

白裂及びチャイナクレーは最も惡い成績を示した。し かも其の涯加量が少くてもまた多くても同じやうに孯い 成績を示したのは注目に值する。

バライト粉及び滑石㸮は前記の二者より良い成績を示 した、バライト粉は添加量が增すと稍成績を低下し、滑 石粉は之に反して源加量が習すと成績が良く成る傾向を 示した。

雲母粉は全體を通じて良い成績を示し、添加量の多少 に依る影響は少かつた。

之等 5 種の體質顏料の5ちで最も早く染膜に缺陷を現 はし始めたものは白㤠であつた。

\section{總 括}

黑鉛に體質顏料を添加する時は一般に曝露成績を低下 する。

其の程度は雲母粉、バライト粉、滑石粉、白垶、チヤ イナクレーの順序に惡くなつた。

\section{顔料の防銹效果に及す體留顔料の影響}

\section{第 5 報 アルミニウム粉一體質顏料系}

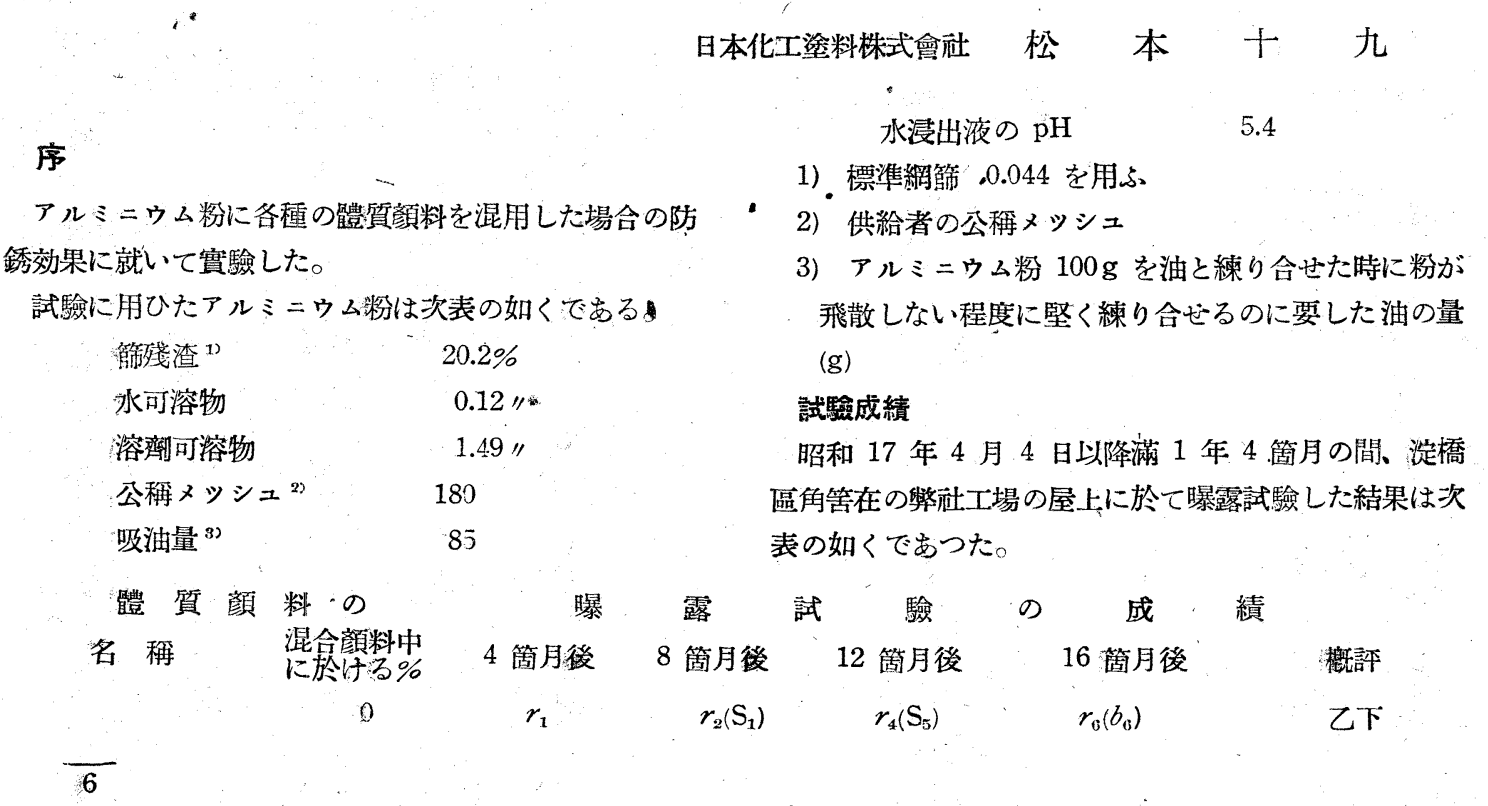




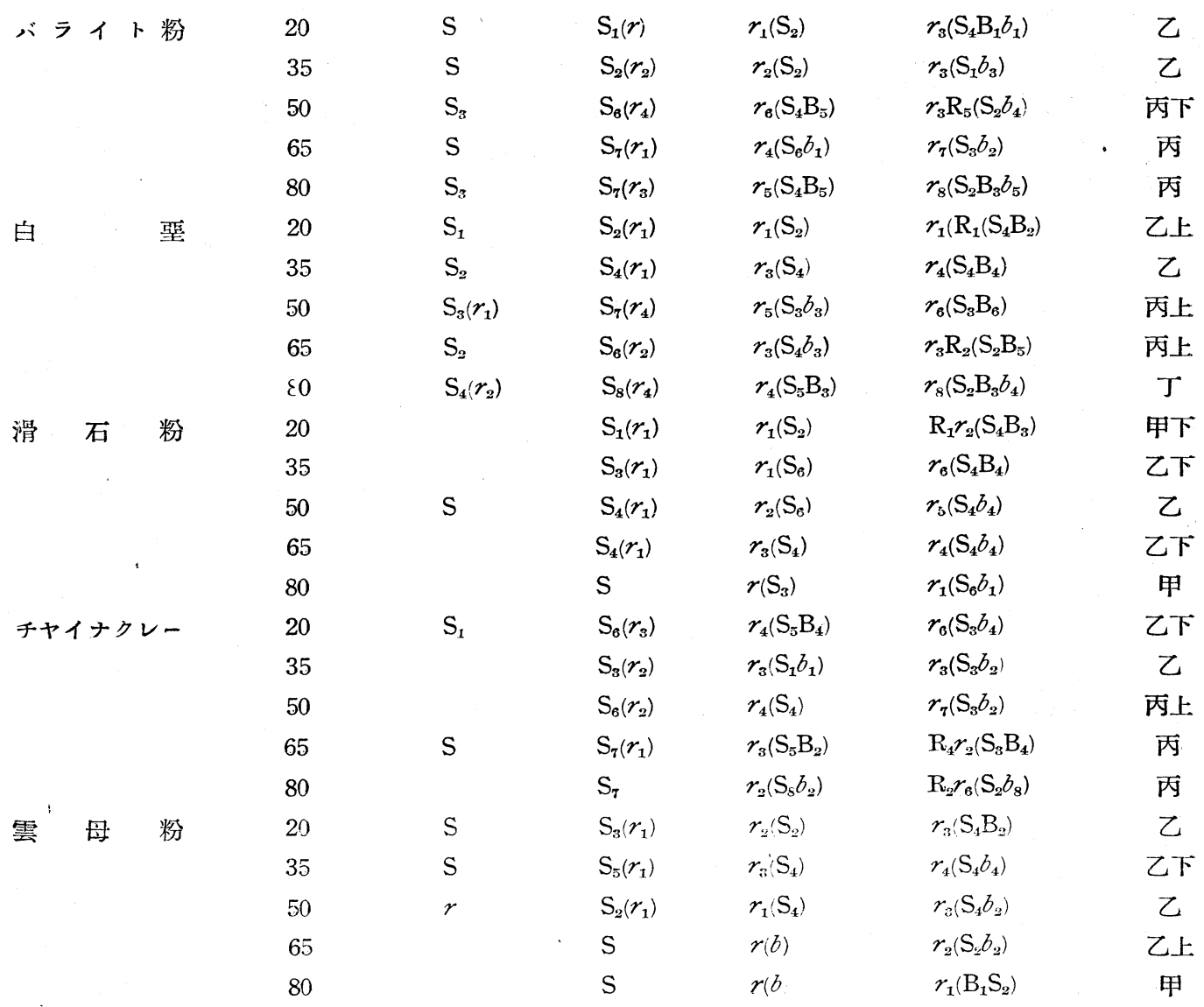

\section{曝露成綪の考察}

アルミニゥムペイントの 1 问塗々膜は比較的早く發銹 のみならず、80\%の如き多量加へた場合には却つてアル ミニウム粉單獨の場合よりも良い成績さへ示した。 之に反してバライト粉、白惡、チヤイナクレー等は其 の傾向を示した。侗狳面は暗化して鼠色に變り光澤を失 つた。また栗粒狀の笑起或は泡起を生じ、其の場所から 銹が大きくなつて逐には塗膜が浮き上つて剥離する狀態 となる倾向が多く、全體として塗面に小突起又は泡起を 生ずる傾向が多かつたのは特異の現能である。

アルミニウム粉の場合には體質顔料の添加に依つて必 ずしも成績が惡くなるもののみとは限らなかつた。即ち 滑石粉及び雲母粉は之を添加しても曝露成績を害せざる の添加量が 35\% 以下の場合には殆んど影響が無いが、 50\%以上加へる時は著しく曝露成績を低下した。

\section{總 括}

アルミニウムペイントは體質顏料の添加が $35 \%$ 以下 の時には無影響で岀る。但し $50 \%$ 以上添加するとバラ イト粉、白裂及チャイナクレーは著しく成績を低下し。 滑石粉及雲母粉は却つて成績が主くなる。

\section{顔料の防銹效果に及す體質顔料の影響}

\section{第 6 報 鉛 丹一體 質 顏 料 系}

序

鉛丹に各種の體質顏料を混用した場合の防銹効果に就
日本化工塗料株式會社 松本十九

いて實驗した。

試驗に用ひた鉛丹は次表の如くである。 


$\begin{array}{lc}\text { 水分 } & 0.25 \% \\ \text { 水可溶物 } & 0.37 \\ \text { 夾雜物 } & 0.4 \\ \text { 四三酸化鉛 } & 82.5 \\ \text { 水镹出液の } \mathrm{pH} & 9.4\end{array}$

\section{試驗成績}

昭和 15 年 5 月 1 日以降滿 3 年牛の間淀橋區角管在 の䌘社工場の屋上に於て曝露試驗した結果は次表の如く であつた。

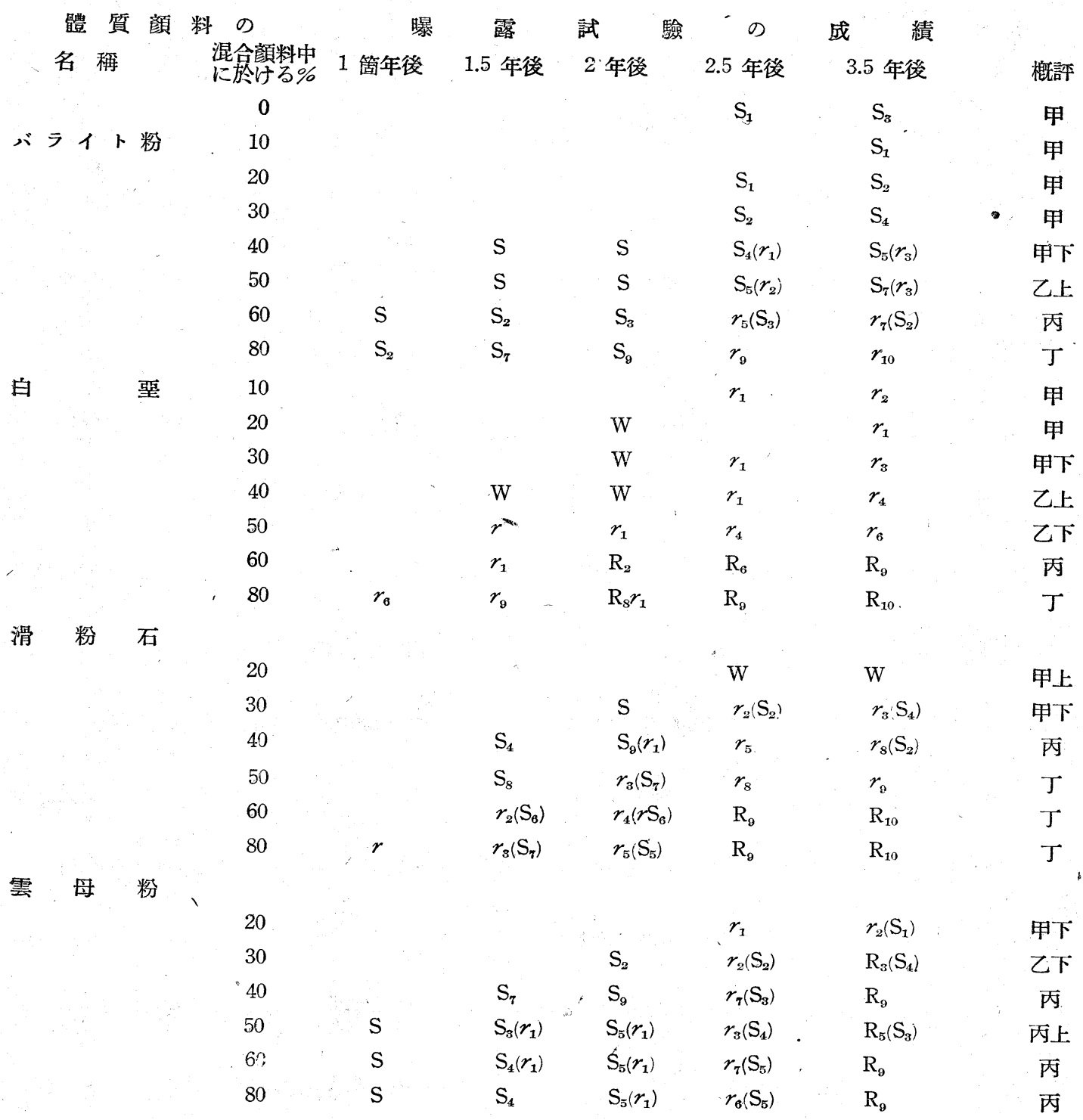

懪露成績の考察 鉛丹に體質顏料を加へる時は一般にる。 防銹効果を減ずるが、其の添加量が少い、時は其の影響は 少い。即ちバライト粉に於ては 30〜 40\%、白垩に於て は 20〜30\%、滑石粉に於ては 20～30\%、雲母粉に於て は $20 \%$. 以下を添加した場合には其の影響は著しくない が、此の範圍以上に添加する時は著しく防銹効果を害寸

佾上記の範圍以內に在つても、バライ小粉の $30 \%$ 以 下、滑石粉の $20 \%$ 以下の添加の場合には、僅に塗膜の 表面が部分的に變色して黄茶色のしみを生ずる程度に過 ぎなかつたが、他の場合には何れる明らかに銹が㜀面に 現はれた。 
またバライト粉添加の場合には澼面に現はれた銹は何

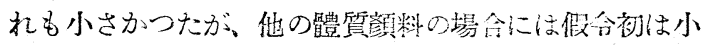
型であつても潮次大型の銹を發生した

成績はバライト粉、白壁、雲母粉及び滑石粉の順序に 惡くなつた。

概して吸油量の多い、體質顔料が惡い成樍を與へて居 る。また同じく吸油量の多い體質顏料の中でも、其の添 加量が 50〜80\% の如く多くなつた場合には、雲母粉の 如く鱗片狀の體質顔料の方が良い成績を示したのは注目 に値する。

\section{塗膜の白罍化}

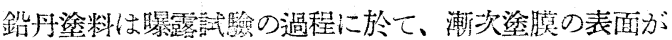
白化する。之は塗膜中の鉛丹が大氣中の炭酸ガス及び水 分の䉆に白色の炭酸鉛に變つた鸪である。

白化した面は段々鼠色に變り、更に進むと表面は白琹 化して指頭を以て摩蔡すると容易に表面が粉末となつて

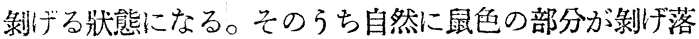
ちて白と鼠色のまだらを生じ、逐には新らしく鉛丹塗料 の赤い面が下から現はれて全面が赤く變るの見る。

しばらく經つと此の新らしい赤い面が再び白化して白 垩化、䡈離する上記の經過を繰り返す

而して此の過程の速度は體質顏料の種類に估つて著し く暴なる。、曝露期關中に此の過程が繰り返して起つた
们數を表示すると次の如くでめる。 體誓頝料

添加量 \% バライト粉 白菿 滑石粉 雲母粉

$\begin{array}{lllll}10 & 1 & 1 & - & - \\ 20 & 1 & 2.5 & 1 & 1 \\ 30 & 1 & 2.5 & 1.5 & \mathrm{~S} \\ 60 & 1 & 2.5 & \mathrm{~S} & \mathrm{~S} \\ 50 & \mathrm{~S} & 2.5 & \mathrm{~S} & \mathrm{~S} \\ 60 & \mathrm{~S} & r & \mathrm{~S} & \mathrm{~S} \\ 80 & \mathrm{~S} & r & \mathrm{~S} & \mathrm{~S}\end{array}$

上表中に於汀る數字は白化、白壁化、酄脫の行程が起 つた可孉を示し、S， $r$ 等は $\mathrm{S}$ 又は $r$ の缺陷が早く現は れた䉆に上記の行程が中絕された事を示す。

郎ち白菿は最も白壁化、剝脫を起し易いことを示して 居る。また一般に體質顏料の添加量が多くなる程白琹 化、剥脫の現像力゙起り易い。

\section{總 括}

吸油量の多い體質顏料の添加は鋁丹の防銹効果を減 ず。郎ちバライト粉、白呿、雲母粉、滑石粉の順に成績 は惡い

バライト粉は $30 \%$ 迄其の他の體質顏料にあつては 20 \%迄加へることが出來る。

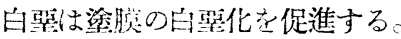

\section{顔料の防銹效果に及す體質顔料の影響 \\ 第 7 報 曝露 成 績 9 總括}

日本化工烝料株式留社 松本十九

\section{序}

著者は前堎文に於て引きつがき酸化鐵粉、ベンガラ、 黑鉆、アルミニウム粉及び鍇丹に谷バライト粉、白瑟、 滑石粉、チヤイナクレー瓜び雲母粉の各種體誓賽料を加

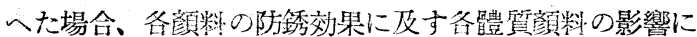
就いて實驗し、其の結果を賏告した

本報交に於ては、前記各報文の成續から各體質顏粘の 機能を防銹滁料用顔料の見地から考究して見たいと思 sac

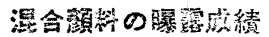

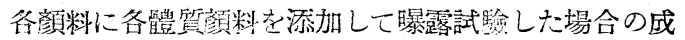
績の順位を表示すると次の如くである。

\section{第 1 表 混入顏料の懪露成績}

\begin{tabular}{|c|c|c|c|c|}
\hline & $\begin{array}{l}\text { 酸化 } \\
\text { 鐵粉 }\end{array}$ & ベン & 黑鉆 & $\begin{array}{l}\text { アルミ } \\
\text { =ウム粉 }\end{array}$ \\
\hline & 15 年 & 1.5 年 & 1 年. & 16 ケ月 \\
\hline
\end{tabular}

體質呅料

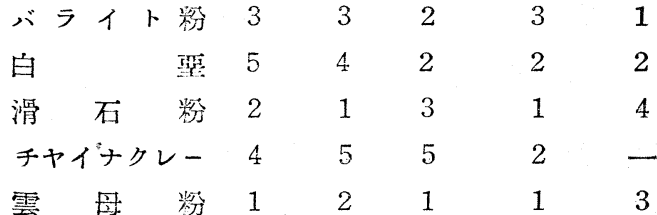

註 表中の數字は成績の順位を示寸。

體質頝料添加の影響は酸化鐵粉以下アルミニウム粉に 於ては略平行した成績を示したが、鉆丹に於ては全く特 
異であつた。

郎ち酸化鐵粉以下アルミニゥム粉に對しては滑石粉及 ぴ雲母粉が好成績を示したのに反して、鉆丹の場合には 之等の體質顏料が却つて惡い成績を示してバライト粉が 良い成樍を示した。

チャイナクレーは一般に腎い成績を示した。

バライト粉は黑鉛と鉆丹の場合を除けば、常に滑石粉 及び雲母粉より惡い成績を示した。またアルミニウム粉 の場合を除けば常に白裂よりも良い成績を示した。

リーフイング性を有する雲母粉は鉛丹以外の顏料に對 しては總べて良い成績を示した。

體質顏料を添加せざる場合と同等以上の良成績を示し た體質顏料の涯加量は第 2 表の如くである。

\section{第 2 表 體質顏料の添加量の影響}

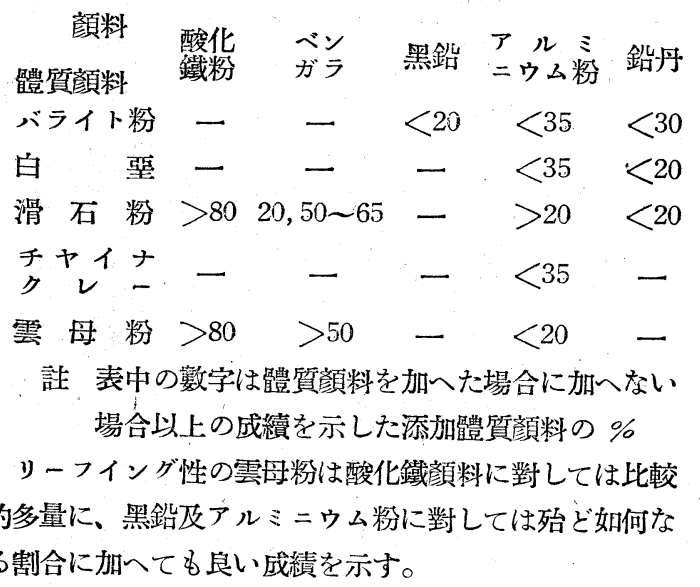

滑石粉は鉛丹に對しては $20 \%$ 以下の少量酸化鐵粉に 對しては多量に、ベンガラに對しては少量叉はかなり多 量に加へた時のみ、:アルミニウム粉に對しては如何なる 割合に加へた時でも良い成績を示した。

バライト粉は黑鉛、アルミラウム粉、鉛丹に少量加一 た時、白堊はアルミニウム粉及び錕丹に少量加一た時、 チヤイナクレーはアルミニウム粉に少量加へた時のみに 良い成績を示しだ

リーフイング性の雲母粉が多量に添加され得ること鉛 丹には吸油量の少い體質顏料程多量に加へ得ること等は 興味ある事實である。

\section{總 括}

1） バライト粉及白垩は添加量の少い方が良い。アル ミニウム粉に對しては 35\%以下、鉛丹に對しては 20 30\%以下が良く、其の他の顏料に對しては加へない方が 良い。白惡は一般にバライト粉に劣る。

2) チヤイナクレーの添加は望ましくない。アルミニ ウム粉に $35 \%$ 以下加へた場合を除けば、常に最も惡い 成績を示した。

3）滑石粉は鉆丹の場合を除けば添加量が多い、程成績 が良い。滑石粉は雲母粉と共に最も成績の良いものの一 つである。

4）雲母粉は鉛丹を除けば渿加量の多い程良い成績を 示した。

5）鈶丹に對しては吸油量の少いバライト粉が良く、 其の他の顏料に對しては雲母粉、又は滑石粉が良い成績 を示した。

\section{メタアクリル酸メチル重合物の塗料化に就て}

\section{東京都立工業獎鉭館化學部 岩 井 信 次}

有機硙子として使用さるるメタアクリル酸メチル重合 物は粘度法による藷者の测定に上れば重合度1800～2300 $\left(\mathrm{Km}=1.8 \times 10^{-4}\right.$ : にして之をベンジールに溶解せしめた るものは高分子量なるため溶液は極めて粘䅕にして、曳 系性甚しく塗料としては極めて不適當である。

塗料として必要なる條件は次の如くである。

(1) 低粘度にして不揮發分多く。例人ば $25 \mathrm{C} に$ 於け る粘度 $=0.6 \sim 1.2$ poise，不揮發分 $=30$ 〜 $50 \%$ 程度を要す る。

（2）更糸性のないこと(樹脂の重合度を適度に低下せ しむることによりて改良さる
（3）乾燥速かにして下地に對する密着性良好なるこ と。

特に (1) の條件を滿足せしもるはメタアクリル酸メチ 儿重合物を塗料とする場合には極めて重要である。

有機硝子はその本質として機械的性質を良好にするた めなるべく重合度の高きものを得んとす。從つて有機硝 子、又は塊狀重合による高重合度樹脂をそのまま溶劑に 溶解したものは不掩發分少く、高粘度にして塗料として は不適當である。然して又心まりに低重合度のものは不 揮發分を多く曳糸性少くなし得るが染膜は脆弱にすぎ、 良好なる機械的性翼を保持せしめることができない。 